\title{
Industry Payments to Nephrologists in the United States
}

Abhinandan R. Pakanati ${ }^{1}$, Karthik Kovvuru ${ }^{2}$, Vaishali Thombre ${ }^{3}$, Swetha Rani Kanduri ${ }^{2}$, Krishna Nalleballe $^{4}$, Saritha Ranabothu ${ }^{5}$

1. Nephrology, The Kidney Clinic, LLC, Snellville, USA 2. Nephrology, Ochsner Medical Center, New Orleans, USA 3. Biostatistics and Epidemiology, University of Arkansas for Medical Sciences, Little Rock, USA 4. Neurology, University of Arkansas for Medical Sciences, Little Rock, USA 5. Pediatrics, University of Arkansas for Medical Sciences, Little Rock, USA

Corresponding author: Abhinandan R. Pakanati, drpakanati@gmail.com

\section{Abstract}

\section{Background}

Industry payments to physicians raise concerns about conflicts of interest that have the potential to impact patient care. In this study, we explored nonresearch and nonownership payments from industry to nephrologists to identify trends in compensation.

\section{Methodology}

Using data from the Centers for Medicare and Medicaid Services (CMS), we explored financial relationships between industry and US nephrologists from 2014 to 2018. We analyzed payment characteristics including payment categories, payment distribution among physicians, regional trends, and biomedical manufacturers.

\section{Results}

In this retrospective study, a total of $\$ 75,174,999$ was paid to nephrologists in the United States during the study period (i.e., 2014-2018). The number of board-certified nephrologists receiving payment from the industry increased from 11,642 in 2014 to 13,297 in 2018. Among board-certified nephrologists, 56\% to 63\% received industry payments during the study period. The total payments to nephrologists increased from $\$ 13,113,512$ in 2014 to $\$ 16,467,945$ in 2017 , with consulting fees (24\%) and compensation for services other than consulting (35\%) being the highest-paid categories. The top $10 \%$ of physician beneficiaries collected $90 \%$ of the total industry payments.

\section{Conclusions}

A small proportion of US nephrologists consistently received the majority of industry payments, the value of which grew over the study period.

Review began 06/24/2021 Review ended 08/01/2021 Published 08/10/2021

\section{○ Copyright 2021}

Pakanati et al. This is an open access article distributed under the terms of the Creative Commons Attribution License CC-BY 4.0., which permits unrestricted use, distribution, and reproduction in any medium, provided the original author and source are credited.

\section{Categories: Nephrology}

Keywords: health economics, industry payment, open payment program, physician beneficiaries, sunshine act, nephrology

\section{Introduction}

Physicians often collaborate with organizations in the healthcare industry. Approximately $94 \%$ of physicians in the United States report some relationship with the industry which ranges from receiving food to being paid for various services [1]. Even though such collaborations can encourage research and patient care, they introduce potential conflicts of interest. For example, receiving industry-sponsored meals has been associated with increased prescription of brand-name medications [2,3]. Industry-sponsored research, compared to nonindustry-sponsored research, shows that these practices have more favorable results and less evidence of harm [4].

Due to concerns about the potential detrimental effects of physician-industry financial relationships, the Centers for Medicare and Medicaid Services (CMS) Open Payments Program (OPP) was initiated by the Physician Payments Sunshine Act of 2009 [5]. CMS OPP mandates public reporting of industry payments made to physicians, teaching hospitals, group purchasing organizations, and medical product manufacturers [6]. Such information about eligible payments has been available through the CMS OPP website since August 2013. Physician-industry financial relationships have been reported in several clinical specialties $[7,8]$, and this study reports the trends and details of such payments in the field of nephrology.

\section{Materials And Methods}




\section{Cureus}

\section{Data sources}

Data on industry payments to nephrologists reported from January 1, 2014, through December 31, 2018, were extracted from the CMS OPP database, and a retrospective analysis was performed. Only general payments were analyzed, and research and partnership payments were excluded. The general payments were divided into nine subcategories (Table 1). The database record for each payment carries a unique physician profile identification, recipient state, sponsor, and related product. Each payment to each physician has a separate entry, even if the physician received multiple payments.

\begin{tabular}{|c|c|}
\hline Subcategory & Definition \\
\hline Consulting fee & $\begin{array}{l}\text { under a written agreement and in response to a particular business need. These payments vary depending on the } \\
\text { experience of the physician being consulted }\end{array}$ \\
\hline Education & $\begin{array}{l}\text { This category generally includes payments or transfers of value for classes, activities, programs, or events that involve the } \\
\text { imparting or acquiring of particular knowledge or skills, such as those used for a profession. This category can include } \\
\text { things like textbooks and medical journal articles }\end{array}$ \\
\hline Entertainment & Attendance at recreational, cultural, sporting, or other events that would generally have a cost \\
\hline Gift & $\begin{array}{l}\text { A general category that often includes anything provided to a physician or teaching hospital that does not fit into another } \\
\text { category }\end{array}$ \\
\hline Grant & Payments to a physician or teaching hospital in support of a specific cause or activity \\
\hline Honoraria & $\begin{array}{l}\text { Similar to consulting fees, but generally reserved for a one-time, short-duration activity. Also distinguishable in that they are } \\
\text { generally provided for services that custom prohibits a price from being set }\end{array}$ \\
\hline Travel and lodging & Travel and lodging \\
\hline Food and beverage & Food and beverage \\
\hline $\begin{array}{l}\text { Compensation for } \\
\text { services other than } \\
\text { consulting }\end{array}$ & Payments made to physicians for speaking, training, and education engagements that are not for continuing education \\
\hline
\end{tabular}

TABLE 1: Nine subcategories of the general payment.

Adopted from https://www.cms.gov/OpenPayments/About/Natures-of-Payment.

\section{Data analysis}

To obtain the total amount paid to each nephrologist, individual payments to each unique physician profile identification were added. From these calculations, $10 \%$ of the nephrologists who received the highest amount of industry payments each year were identified. For each year, the sum of all payments received by the top $10 \%$ of nephrologists was calculated as a proportion of the total amount of industry payments.

Using the total number of nephrologists in the United States as a denominator, we calculated the proportion of nephrologists who received industry payments. The mean, median, minimum, maximum, and 90th percentile were calculated for these payments. To explore the distribution of payments among US nephrologists, we calculated the Gini index (a statistical measure of dispersion) for physicians who received any payment each year. The Gini index ranges from 0 (all physicians received an equal number of payments) to 1 (one physician received all the payments).

\section{Results}

Results of this retrospective study revealed that the industry paid a total of $\$ 75,174,999$ to US nephrologists during the study period 2014-2018 (Table 2). Total payments to nephrologists increased slowly and persistently from 2014 to 2017 , with a slight downward trend noted in 2018. The number of board-certified nephrologists increased from 11,642 in 2014 to 13,297 in 2018; 56-63\% of board-certified nephrologists received industry payments during the study period. Each year, about 7,300 nephrologists received payments, and the top $10 \%$ received $90 \%$ of the total payments. Mean payments $(\$ 1,795-\$ 2,227)$ were substantially higher than the median payments $(\$ 145-\$ 184$ ) (Table 3). The Gini index ranged from 0.90 to 0.92 (Table 3). 


\section{Cureus}

\begin{tabular}{|c|c|c|c|c|c|c|c|}
\hline Year & General payment & Percentage & Research payment & Percentage & Ownership payment & Percentage & Total \\
\hline 2014 & $\$ 13,113,512$ & $68 \%$ & $\$ 1,540,777$ & $8 \%$ & $\$ 4,585,718$ & $24 \%$ & $\$ 19,240,007$ \\
\hline 2015 & $\$ 14,659,590$ & $69 \%$ & $\$ 2,951,263$ & $14 \%$ & $\$ 3,718,113$ & $17 \%$ & $\$ 21,328,967$ \\
\hline 2016 & $\$ 15,504,983$ & $79 \%$ & $\$ 2,748,154$ & $14 \%$ & $\$ 1,263,222$ & $6 \%$ & $\$ 19,516,359$ \\
\hline 2017 & $\$ 16,467,945$ & $64 \%$ & $\$ 1,617,353$ & $6 \%$ & $\$ 7,669,002$ & $30 \%$ & $\$ 25,754,300$ \\
\hline 2018 & $\$ 15,428,969$ & $80 \%$ & $\$ 241,579$ & $1 \%$ & $\$ 3,624,535$ & $19 \%$ & $\$ 19,295,082$ \\
\hline Total & $\$ 75,174,999$ & $72 \%$ & $\$ 9,099,126$ & $9.7 \%$ & $\$ 20,860,590$ & $20.7 \%$ & $\$ 105,134,715$ \\
\hline
\end{tabular}

TABLE 2: Summary of payments from industry to board-certified nephrologists (2014-2018).

\begin{tabular}{|c|c|c|c|c|c|}
\hline Payment descriptor & 2014 & 2015 & 2016 & 2017 & 2018 \\
\hline Board-certified nephrologists & 11,642 & 12,129 & 12,567 & 12,944 & 13,297 \\
\hline Board-certified nephrologists receiving payment ( $\%$ of total) & $7,304(63 \%)$ & $7,199(59 \%)$ & $7,308(58 \%)$ & $7,394(57 \%)$ & $7,393(56 \%)$ \\
\hline Total value of payments & $\$ 13,113,512$ & $\$ 14,659,590$ & $\$ 15,504,983$ & $\$ 16,467,945$ & $\$ 15,428,969$ \\
\hline Mean payment & $\$ 1,795$ & $\$ 2,036$ & $\$ 2,122$ & $\$ 2,227$ & $\$ 2,087$ \\
\hline Standard deviation & $\$ 18,945$ & $\$ 14,620$ & $\$ 14,504$ & $\$ 14,358$ & $\$ 13,501$ \\
\hline Median payment & $\$ 147$ & $\$ 145$ & $\$ 156$ & $\$ 184$ & $\$ 179$ \\
\hline Interquartile range & $\$ 296$ & $\$ 323$ & $\$ 345$ & $\$ 415$ & $\$ 415$ \\
\hline Gini index & 0.92 & 0.91 & 0.92 & 0.91 & 0.90 \\
\hline Total amount received by the top $10 \%$ of nephrologists & $\$ 11,848,107$ & $\$ 13,294,746$ & $\$ 14,045,348$ & $\$ 14,802,345$ & $\$ 13,787,134$ \\
\hline Percentage of total value of payments & $90 \%$ & $91 \%$ & $91 \%$ & $90 \%$ & $89 \%$ \\
\hline Maximum payment & $\$ 1,091,314$ & $\$ 680,304$ & $\$ 459,664$ & $\$ 527,635$ & $\$ 648,182$ \\
\hline Top 10 physician payments & $\$ 3,863,967$ & $\$ 2,765,727$ & $\$ 2,850,077$ & $\$ 2,764,036$ & $\$ 2,573,686$ \\
\hline Percentage of top 10 physician payments & $29 \%$ & $19 \%$ & $18 \%$ & $17 \%$ & $17 \%$ \\
\hline
\end{tabular}

TABLE 3: Characteristics of general payments to nephrologists (2014-2018).

The three highest payment categories, namely, speaker fee (35\%), consulting fee (24\%), and travel and lodging (15.6\%), were consistently prominent throughout the study period (Table 4). Compensation for continuing medical education remained surprisingly low throughout the study period, but compensation for food and beverage trended linearly upward from 2014 to 2017 (\$1,740,090 to $\$ 2,369,407)$. Interestingly, physician payments for royalties or licenses were moderately high in 2014 but trended downward in subsequent years. 


\section{Cureus}

\begin{tabular}{|c|c|c|c|c|c|c|}
\hline Category & 2014 & 2015 & 2016 & 2017 & 2018 & Total \\
\hline Charitable contribution & $\$ 20,000$ & $\$ 1,000$ & $\$ 25,000$ & - & $\$ 30,603$ & $\$ 76,603$ \\
\hline Compensation for service & $\$ 2,374,739$ & $\$ 5,145,838$ & $\$ 6,185,955$ & $\$ 6,854,196$ & $\$ 5,978,104$ & $\$ 26,538,832$ \\
\hline Consulting fee & $\$ 3,286,599$ & $\$ 4,135,067$ & $\$ 3,181,342$ & $\$ 3,947,520$ & $\$ 3,844,884$ & $\$ 18,395,411$ \\
\hline Current or prospect & - & - & $\$ 350$ & - & - & $\$ 350$ \\
\hline Education & $\$ 205,789$ & $\$ 70,525$ & $\$ 74,054$ & $\$ 199,561$ & $\$ 73,044$ & $\$ 622,973$ \\
\hline Entertainment & $\$ 2,139$ & $\$ 225$ & $\$ 8,555$ & $\$ 1,816$ & $\$ 94$ & $\$ 12,829$ \\
\hline Food and beverage & $\$ 1,740,090$ & $\$ 1,873,092$ & $\$ 2,061,513$ & $\$ 2,369,407$ & $\$ 2,314,527$ & $\$ 10,358,629$ \\
\hline Gift & $\$ 7,818$ & $\$ 5,185$ & $\$ 58,899$ & $\$ 26,975$ & $\$ 8,167$ & $\$ 107,045$ \\
\hline Grant & $\$ 13,461$ & $\$ 13,275$ & $\$ 66,200$ & $\$ 50,723$ & $\$ 1,167$ & $\$ 144,826$ \\
\hline Honoraria & $\$ 1,704,677$ & $\$ 355,907$ & $\$ 1,083,312$ & $\$ 435,798$ & $\$ 822,202$ & $\$ 4,401,896$ \\
\hline Royalty or license & $\$ 1,792,183$ & $\$ 445,715$ & $\$ 337,888$ & $\$ 87,356$ & $\$ 50,072$ & $\$ 2,713,214$ \\
\hline Travel and lodging & $\$ 1,966,017$ & $\$ 2,613,761$ & $\$ 2,421,915$ & $\$ 2,494,594$ & $\$ 2,306,105$ & $\$ 11,802,392$ \\
\hline Total & $\$ 13,113,512$ & $\$ 14,659,590$ & $\$ 15,504,983$ & $\$ 16,467,945$ & $\$ 15,428,969$ & $\$ 75,174,999$ \\
\hline
\end{tabular}

TABLE 4: Categories of general payments to nephrologists (2014-2018).

Veltassa, Acthar, and Auryxia were the drugs most commonly associated with payments to nephrologists in 2018 (Table 5). These drugs consistently ranked high among the drugs associated with payments from 2016 to 2018. Soliris was one of the top drugs associated with the highest payments to nephrologists in 2016, but payments associated with Soliris decreased in 2017 and 2018. 


\section{Cureus}

\begin{tabular}{|c|c|c|c|c|c|c|c|c|c|}
\hline \multicolumn{2}{|l|}{2014} & \multicolumn{2}{|l|}{2015} & \multicolumn{2}{|l|}{2016} & \multicolumn{2}{|l|}{2017} & \multicolumn{2}{|l|}{2018} \\
\hline Drug/Device & $\begin{array}{l}\text { Sum of } \\
\text { payments }\end{array}$ & Drug/Device & $\begin{array}{l}\text { Sum of } \\
\text { payments }\end{array}$ & Drug/Device & $\begin{array}{l}\text { Sum of } \\
\text { payments }\end{array}$ & Drug/Device & $\begin{array}{l}\text { Sum of } \\
\text { payments }\end{array}$ & Drug/Device & $\begin{array}{l}\text { Sum of } \\
\text { payments }\end{array}$ \\
\hline$N / A^{\#}$ & $\$ 5,254,268$ & $N / A^{\#}$ & $\$ 4,105,328$ & $N / A^{\#}$ & $\$ 2,336,365$ & $N / A^{\#}$ & $\$ 2,688,686$ & $N / A^{\#}$ & $\$ 2,435,404$ \\
\hline Acthar & $\$ 2,184,522$ & Acthar & $\$ 1,672,232$ & Acthar & $\$ 2,100,424$ & Acthar & $\$ 1,674,653$ & Veltassa & $\$ 1,748,937$ \\
\hline Soliris & $\$ 696,385$ & Soliris & $\$ 1,632,666$ & Veltassa & $\$ 1,344,142$ & Veltassa & $\$ 1,504,282$ & Acthar & $\$ 1,607,383$ \\
\hline Sensipar & $\$ 564,627$ & Auryxia & $\$ 1,136,523$ & Soliris & $\$ 1,191,279$ & Velphoro & $\$ 986,230$ & Auryxia & $\$ 1,028,136$ \\
\hline Invokana & $\$ 366,892$ & Velphoro & $\$ 861,981$ & Velphoro & $\$ 815,135$ & Soliris & $\$ 950,499$ & Parsabiv & $\$ 978,166$ \\
\hline Samsca & $\$ 307,925$ & Sensipar & $\$ 451,259$ & Auryxia & $\$ 687,898$ & Parsabiv & $\$ 925,652$ & Velphoro & $\$ 746,597$ \\
\hline Bydureon & $\$ 305,322$ & Fabrazyme & $\$ 363,125$ & Samsca & $\$ 598,621$ & Samsca & $\$ 797,734$ & Jynarque & $\$ 668,011$ \\
\hline Fabrazyme & $\$ 272,039$ & Invokana & $\$ 357,232$ & Invokana & $\$ 590,270$ & Invokana & $\$ 594,591$ & Soliris & $\$ 455,594$ \\
\hline Renvela & $\$ 259,388$ & Bydureon & $\$ 338,018$ & Sensipar & $\$ 555,172$ & Tradjenta & $\$ 594,269$ & Invokana & $\$ 440,035$ \\
\hline Rituxan & $\$ 199,044$ & Uloric & $\$ 337,099$ & Farxiga & $\$ 533,527$ & Farxiga & $\$ 444,203$ & Tradjenta & $\$ 369,155$ \\
\hline Noncovered & $\$ 168,164$ & Renvela & $\$ 329,853$ & $\begin{array}{l}\text { System } \\
\text { One }^{\star}\end{array}$ & $\$ 432,312$ & Auryxia & $\$ 380,276$ & Samsca & $\$ 316,473$ \\
\hline
\end{tabular}

TABLE 5: Leading manufacturers and drugs associated with the highest amounts of payments to board-certified nephrologists (2014-2018).

\#N/A: not applicable, drug information not provided.

*System One hemodialysis machine is a device manufactured by NxStage Medical, Inc. (Lawrence, Massachusetts, USA).

\section{Discussion}

The present study used the CMS OPP database to explore the financial relationships between industry and US nephrologists over a five-year period. Results revealed that total payments increased from 2014 to 2017 , which was followed by a downturn in 2018. Although the exact reason for this trend is unclear, it could be related to changes in the industry's activities due to OPP and the Sunshine Act. However, it is unclear whether underreporting occurred.

Additionally, even though the number of board-certified nephrologists increased during the study period and annual payments to nephrologists increased tremendously, the proportion of nephrologists receiving payments remained relatively stable throughout the study period. Similar to results reported for other subspecialties, such as cardiology and vascular neurology $[9,10]$, we report substantial inequality among nephrologists receiving industry payments. Overall, $90 \%$ of the total payments were received by only $10 \%$ of the nephrologists. This pattern of skewed payments may be related to industries targeting physicians who are perceived as leaders in the field with the ability to influence the practice patterns of other physicians $[11,12]$. It is encouraging that most nephrologists did not receive significant payments, so they are not particularly prone to the potential biases introduced by financial relationships with the industry.

Compensation for services, consulting fees, and travel and lodging consistently remained the top payment categories throughout the study period. Categories varied widely among different specialties, with royalties and licensing accounting for the highest-paid category among surgical specialties $[13,14]$. Consistent with reports from other medical subspecialties, our results showed that payments were the largest for engagements related to noneducational activities [15]. In nephrology, medications remain important categories for industrial payments, which differs from the field of vascular neurology in which payments shifted from pharmacological utilities to medical devices [9].

A few limitations of our study must be noted. Our retrospective analysis is based on information obtained from the CMS OPP database, which could have ambiguities and incomplete records. Potential inaccuracies may result from the retrospective nature of the study and its reliance on self-reported data. Additionally, nephrologists who are not board-certified were excluded. We did not explore research and ownership payments by the industry and their compensation trends. Finally, we could not report the most recent trends (i.e., 2020-2021) because we were limited by data collected through 2018. 


\section{Conclusions}

We report that the industry paid the greatest amount of money to a small percentage of nephrologists, which was consistent throughout the study period. Controversy continues to surround financial relationships between industry and physicians, as well as the potential influence of these relationships on research and patient care. Further studies are warranted to help overcome the limitations of the present study and to increase our understanding of financial conflicts of interest and the subsequent impact on patient care.

\section{Additional Information}

\section{Disclosures}

Human subjects: All authors have confirmed that this study did not involve human participants or tissue. Animal subjects: All authors have confirmed that this study did not involve animal subjects or tissue. Conflicts of interest: In compliance with the ICMJE uniform disclosure form, all authors declare the following: Payment/services info: All authors have declared that no financial support was received from any organization for the submitted work. Financial relationships: All authors have declared that they have no financial relationships at present or within the previous three years with any organizations that might have an interest in the submitted work. Other relationships: All authors have declared that there are no other relationships or activities that could appear to have influenced the submitted work.

\section{References}

1. Campbell EG, Gruen RL, Mountford J, Miller LG, Cleary PD, Blumenthal D: A national survey of physicianindustry relationships. N Engl J Med. 2007, 356:1742-50. 10.1056/NEJMsa064508

2. Brennan TA, Rothman DJ, Blank L, et al.: Health industry practices that create conflicts of interest: a policy proposal for academic medical centers. JAMA. 2006, 295:429-33. 10.1001/jama.295.4.429

3. Sharma M, Vadhariya A, Johnson ML, Marcum ZA, Holmes HM: Association between industry payments and prescribing costly medications: an observational study using open payments and medicare part D data. BMC Health Serv Res. 2018, 18:236. 10.1186/s12913-018-3043-8

4. Bero L: Industry sponsorship and research outcome: a Cochrane review. JAMA Intern Med. 2013, 173:580-1. 10.1001/jamainternmed.2013.4190

5. Agrawal S, Brennan N, Budetti P: The Sunshine Act--effects on physicians . N Engl J Med. 2013, 368:2054-7. 10.1056/NEJMp1303523

6. Fleischman W, Agrawal S, King M, et al.: Association between payments from manufacturers of pharmaceuticals to physicians and regional prescribing: cross sectional ecological study. BMJ. 2016, 354:i4189. 10.1136/bmj.i4189

7. Dandu V, Siddamreddy S, Thombre V, et al.: A five-year analysis of industry payments to sleep neurologists from 2014 through 2018. Cureus. 2020, 12:e10597. 10.7759/cureus.10597

8. Nalleballe K, Veerapaneni KD, Harada Y, et al.: Trends of industry payments in neurology subspecialties . Cureus. 2020, 12:e9492. 10.7759/cureus.9492

9. Nalleballe K, Sheng S, Li C, et al.: Industry payment to vascular neurologists: a 6-year analysis of the Open Payments Program from 2013 through 2018. Stroke. 2020, 51:1339-43. 10.1161/STROKEAHA.119.027967

10. Annapureddy A, Sengodan P, Mahajan S, Annapureddy T, Murugiah K, Desai NR, Curtis JP: Distribution of industry payments among medical directors of catheterization and electrophysiology laboratories from the top 100 US hospitals. JAMA Intern Med. 2019, 179:1282-4. 10.1001/jamainternmed.2018.8775

11. Annapureddy A, Murugiah K, Minges KE, Chui PW, Desai N, Curtis JP: Industry payments to cardiologists. Circ Cardiovasc Qual Outcomes. 2018, 11:e005016. 10.1161/CIRCOUTCOMES.118.005016

12. Moynihan R: Key opinion leaders: independent experts or drug representatives in disguise? . BMJ. 2008, 336:1402-3. 10.1136/bmj.39575.675787.651

13. Chao AH, Gangopadhyay N: Industry financial relationships in plastic surgery: analysis of the Sunshine Act Open Payments Database. Plast Reconstr Surg. 2016, 138:341e-8e. 10.1097/PRS.0000000000002404

14. Wong VS, Avalos LN, Callaham ML: Industry payments to physician journal editors. PLoS One. 2019, 14:e0211495. 10.1371/journal.pone.0211495

15. Harada Y, Sheng S, Thombre VA, et al.: A neuromuscular-based analysis of the open payments program . Muscle Nerve. 2021, 63:96-9. 10.1002/mus.27016 